\title{
TRIBUNA
}

H ace ya algún tiempo se han estado discutien do en el sen o de la sociedad chilena cambios a las actuales disposiciones sobre los derechos autorales, análisis que últimamente se ha agu dizado como con secuen cia de haberse presentado en el Congreso $\mathrm{Nacional}$ un proyecto de Ley de Propiedad Intelectual. Considerando la importancia y trascendencia que tiene el asunto en discusión para la creación artística, la Revista M usical Chilena ha pedido la opinión a cuatro actores relevantes de dicha compleja situación ética y legal.

\section{Por una cultura del respeto}

Si hay algo que caracteriza a las sociedades modernas es su permanente e incesante impulso de transformación. Algo que naturalmente lleva apareado una necesidad, también permanente, de regulación y control. Las leyes, que son expresión fidedigna de lo anterior, son a su vez el último eslabón de esos procesos de transformación. De aquí que por un lado sean el resultado de ese vertiginoso dinamismo y, por otro, el instrumento por el cual las comunidades se autorregulan formalmente ante nuevas realidades, buscando en ello satisfacer eficaz y equilibradamente intereses múltiples, muchas veces en franco antagonismo.

Lo anterior adquiere pleno significado y sentido hoy, que advertimos con profunda preocupación la situación que afecta a la comunidad cultural, situación derivada del proyecto de Ley de Propiedad Intelectual que actualmente se discute en el Congreso de nuestro país, pues precisamente tiene que ver con estas transformaciones de las que hablamos. Ahora bien, para nosotros este proyecto de ley no cumple su tarea si no se concibe y articula complejamente, es decir, integral y equilibradamente. Tenemos una gran oportunidad para deshacer un desequilibrio y una injusticia endémica en nuestra cultura. Los autores y artistas son, como los demás miembros de la comunidad, partes de un todo indivisible, de modo que deben ser considerados con el mismo respeto y dignidad que los demás miembros de las industrias llamadas culturales o comerciales.

Ha llegado la hora de dar un salto cualitativo en nuestra comprensión del fenómeno cultural. La dificultad que obstruye este salto es que nuestros legisladores trabajan prisioneros de la noción de propiedad intelectual que nos legó la tradición platónica, es decir, aquella que permite dotar a las creaciones artísticas e intelectuales de valor, pero difícilmente de precio. Para decirlo de otra manera: hasta hace poco (y dependiendo de cada país) la división entre los distintos regímenes de producción, daba origen a la paradoja que los bienes tangibles tuviesen precio, en cambio los bienes intangibles (artísticos o culturales) sólo tuvieran valor. Vale decir, uno tenía derecho a cobrar por hacer un par de calcetines, pero no lo tenía por la difusión de un guión por televisión. En la actual cultura de los inter- 
cambios pragmáticos, esa dicotomía no tiene sentido, advirtiendo eso sí que, no por ello, se confunden sus diferencias simbólicas específicas a cada régimen de producción.

Vivir del fruto de su trabajo es el anhelo de todos los seres humanos. También lo es de los autores y artistas. En este sentido y al margen de la legítima decisión personal de cada cual a ejercer su derecho, insistir en promover la gratuidad de los bienes intangibles en una sociedad y economía mundial donde todo tiene precio es, por decir lo menos, anacrónico. Ha sido pues el propio desarrollo histórico el que ha abierto la posibilidad de salir de esa entelequia platónica que relegaba la obra artística a la trascendencia metafísica y al artista a la pobreza. En pocas palabras, el nuevo hábitat tecnológico, social y cultural impulsado por la globalización del pragmatismo, han conseguido que el trabajo intelectual y artístico, al igual que el técnico y manual, puedan deshacer esas viejas y lamentablemente todavía arraigadas injusticias.

Cuando se apela a un trato justo, se lo hace por tanto a la comprensión compleja de nuestra condición cultural e histórica. Querer mantener el modelo metafísico de cultura en el nuevo contexto económico y social se ha vuelto, cuando menos, problemático. De hecho, más allá de la información confusa que se entrega por los medios, es la propia comunidad la que exige un trato justo para sus autores y artistas y es ella misma la que no puede entender que los intermediarios entre las obras y el público insistan en culpar a los creadores por defender sus legítimas aspiraciones económicas por su trabajo. Es hora que la sensatez triunfe y todos juntos obtengamos lo que es justo, pues lo que está en juego es algo más que una ley y un principio de justicia: es nuestra propia dignidad como sociedad civil madura y equilibrada.

Gustavo M eza Wevar

Presidente

Sociedad de Autores $\mathrm{N}$ acionales de Teatro, Ciney Audiovisuales (ATN),

Chile

info@atn.cl

\section{Derechos de autor: la nueva actitud}

Antes de que aparecieran la sociedad global y los países emergentes, el mundo se estructuraba piramidalmente, o quizá siguiendo un formato bipolar. Éramos capitalistas o anticapitalistas, desarrollados o subdesarrollados, protagonistas o actores muy, muy secundarios. A partir de la revolución digital el mundo se ha interconectado. Y precisamente por la mayor homogeneidad tecnológica, política o económica, el tejido social ha dejado de ser visto como una sola cosa. Surgen las minorías, aparecen los contrastes, los relieves, las diferencias. No sólo quiere ser cada cual tratado de manera digna, sino que hay mayor rechazo a la discriminación. Desde el género, las mujeres no tienen ya más paciencia para la violencia doméstica ni para la discriminación laboral. Los homosexuales están hartos de 